\title{
Shia Armed Groups and the Future of Iraq
}

\author{
Kardo Rached \\ University of Human Development \\ College of Law and Politics \\ Sulaymaniayh, Iraq \\ e-mail: kardo.rached@uhd.edu.iq
}

\section{Ahmed Omar Bali}

University of Human Development e-mail: abdullah@uhd.edu.iq

\section{Abstract}

The rising and acceleration of the Shia armed group in Iraq, Syria, Yemen, and Lebanon require a deep understanding of the root of the multi-dimensional conflicts in the Middle East. An appropriate and sufficient approach to the research about these militias will be from an internal conflict rather than an external conflict. The legitimization for the existence of the majority of these militias if not all of them is to fight and struggle against an entity which is the Sunni sect, in this case, that will assimilate them not integrate them peacefully.

Keywords: Iraq, Iran, Shia armed groups, Sectarian division, ISIS, New Middle East and Religious violence 
In this article, we try to identify the impact of the Shia militias in Iraq on the formation of the future of this country. We maintain that these armed groups will be a destabilizing factor for Iraq and its neighbors, and they will worsen and deepen the sectarian division in the Middle East.

We assess these different groups from different perspectives, for example, using the Weberian theory that the state is the only entity that has a monopoly of violence, Ariel Ahram's model of state-sponsored and government-sponsored militias, and finally the devolution of violence to these armed groups.

\section{Introduction}

In this paper, we will introduce the political situation in Iraq since the Islamic State in Iraq and Syria (ISIS) took over the second most populated city, Mosul, in 2014. It is important to highlight that the main purpose of this paper is to investigate the impact of the Shia militias on the formation of the future of Iraq and peaceful coexistence within Iraqi society.

Following the collapse of the Iraqi regime in 2003, the American and British forces faced multiple problems, such as security issues, gaps in the system, and a lack of fundamental services such as water and electricity. The White House decided to send their strongman Paul Bremer as their military representative to serve as the leader of the coalition in Iraq, Bremer's role was to create a new Iraqi regime based on the American perspective. The main idea of Bremer's plan was to reform a new Iraq under the concept of "ethnic power sharing". From this point on, Iraq has been divided into three main sects: Kurds, Sunni, and Shia. The re-creation process of the new Iraqi political system has resulted in the sectarianism found in Iraqi society since 2003.

The first step in this direction started with the so-called Iraqi governing council (Majlis Alhukem) replacing Saddam Hussein's government. Majles Hukem consisted of representatives from the main Iraqi ethnic groups, and the intention was to create a roadmap for a new constitution and the formation of a new government. Ironically, many members of the Majles Hukm had only returned to Iraq with the American and British forces and were unpopular among the majority of Iraqi society. Through the Majlis Hukm, Shia politicians could impose their conditions on the others. In the beginning, they were able to achieve an agreement with the Kurds regarding the senior positions in the Iraqi government. For example, the Shias should be given the prime minister's position because they were/are the majority, but the Kurds could receive the president's position. The division of the highly important positions between the two groups left the Sunnis feeling excluded from the political process. Therefore, the majority of the Sunnis chose to support the rebel groups against the coalition forces and the Iraqi government. The development of sectarianism 
in Iraqi society became the basis for the reconstruction of state institutions, and this had been reflected in all the state apparatus. For example, the new Iraqi military and the intelligence agency were the under control of the Shia, and the country's foreign affairs were in the hands of the Kurds.

The turning point for Iraqi society was June 10, 2014, when ISIS took control of the second largest city in Iraq, Mosul. The Iraqi government lost the majority of its Sunni cities and population to ISIS. Moreover, the Iraqi military lost its willingness to fight in many Sunni areas because the population did not consider the Shia soldiers to be a national army. This new phase of political turbulence and the expansion of violence started when the Iraqi army lost its moral in the fight against ISIS fighters. This resulted in calling for the organization of the Shia people into the so-called People's Mobilization Forces (PMF), in Arabic the Hashed Shabi, against ISIS.

\section{Historical review of the state-creation in Iraq}

The process of state-building in Iraq has a long and complicated history. The first phase of the state-building process in Iraq is going back to the British occupation of the Wulyat of Bagdad during the First World War. Under the British occupation, the state building process was started and intensified. The British tried to form Iraq in accordance with their interest. Their first step in this direction was the integration of the 3 Wulyat (Wulyat Baghdad, Mousel, Basra) into one state under the King Faisal authority. They supported king Faisal financially and politically in order to consolidate and concentrate power in his hand. Both British and the king faced multiples problems in their effort to frame the Iraqi society and its state. According to Charles Tripp, it was in British interest to institutionalize the new Iraqi state. On the one hand, they could by institutionalization process dominate the Iraqi society and through it, they would absorb the power in hands of King.

On the other hand, they could also avoid blaming of the direct rule as it was the main reason for the many revolts against them during the transition power to King Faisal. Administratively, the new Iraqi state was born but it experienced challenging time by time. The Iraqi monarchy rule was continued until 1958. During these years the Iraqi political system and society formed 12 times Parliament. But it didn't help to cement democracy into Iraq. In opposite to that, it enriched the tribalism and conservatism because the most of the candidates were elected to Parliament labeled as landowners, tribals, and religious leaders. The state building process in Iraq since the First World War came as a result of intervention from an external power which created a weak and unstable state.

The second phase of the state rebuilding process started after a military coup against the Iraqi royal rule. The military - Arab nationalism came to power in 1958 and abolished the monarchy in Iraq forever. The coalition of Arab socialism 
- nationalism with military root, cooperated to rebuild the Iraq state in the direction that the Arab race superiority became a cornerstone for a new Iraq. The postMonarch Iraq described as a single party rule. It makes the new Iraq a state with intra-ethnic conflict. The eruption of the ethnic conflict and the systematical suppression of minority such as Kurds reflected in the mind and behavior of the state. It puts Iraq into security dilemma.

The third phase of this process begins with the Iraqi invasion of Kuwait. Since the Iraqi defeated in Kuwait in 1990 and the UN decision of the economic and military sanction against the Saddam regime, the Iraqi state's institutions met unbearable requirements from its citizens. Politically and economically the Iraqi state was unable to fulfill its functional responsibilities. It changed the image of the Iraqi state from the defender of the Arabs against the Persians to be a weak state that was unable to defend itself. The Iraqi state could survive the pressure and requirements from the international community for delivering its nuclear weapons until 2003 but before this time, the Iraqi state could never come back to its earlier form as a realistic state, that fought against the Iranian regime during 8 years. And beside it, the Iraqi regime didn't accept the Kurdish guerrilla's challenge against its monopoly over violence. it started a comprehensive military campaign against them in the north. Until 2003 the Iraqi state was seen as a weak state that was more close to collapse.

The Iraqi state in post-2003 is a difficult and complex entity. The regime changing in Iraq by US and UK in 2003 meant the new process for the rebuilding and recreating a new Iraq, was started and based on the basis of ethnic power-sharing. Despite numerous problems that faced the post-Saddam government in Baghdad, it continued until the dramatically and catastrophically defeat of the Iraqi army and security institutions in many Sunni cities against ISIS in 2014. From that perspective, the Iraqi army and its security institutions lost its capacity and ability to fight. It forced the former Iraqi government to ask Shia cleric Ali Sistani to make a Fatwa and calling the young Shia in the whole Iraq to fight against ISIS under the authority of the popular mobilization forces (MPF). That made it possible and legitimate for the creation and spreading non-state armed Shia groups in Iraq. By controlling the state institutions, (MPF) became an important umbrella for the most Shia political parties and now through joining the (MPF), the Shia politicians provide a popular support among Iraqi Shia.

\section{An overview of the Popular Mobilization Forces}

According to al-hashed.net which is an official website for the PMF, the structure of it consists of the following:

PMF has a leader with a deputy chairman (Alhaj Abu Mahdi Almuhandis) then the sixteen directorates linked to the deputy chairman. 
These directorates include the following:

1. Directorate Inspector General;

2. Directorate of Administration;

3. Directorate of Finance;

4. Directorate of Planning;

5. Directorate of Operations;

6. Directorate of Logistics Support;

7. Directorate of Information;

8. Directorate of ideological guidance;

9. Directorate of Medicine;

10. Directorate of Training;

11. Directorate of Central Security;

12. Directorate of Packing;

13. Directorate of martyrs and wounded;

14. Directorate of Military Engineering;

15. Directorate of Communications;

16. Directorate of Intelligence;

17. Artillery Battalion;

18. Armored Corps Battalion;

19. Tank Battalion;

20. Bridges of Popular Forces.

The Directorate of ideological guidance takes care of the guiding of the Mujahideen and mobilizes them with true jihadist concepts and building the mujahideen in a religious and doctrinal construction. It is sending students from Hawza al-elmyia (an Islamic Shia school from Najaf in Iraq and Qum in Iran) into the front lines in the battlefields. They are responsible for the following issues:

1. The ideal religious preparation of the Mujahideen.

2. Raise the cultural and religious level of the Mujahideen.

3. Increase awareness and insight of the Mujahideen.

4. Raise the morale and jihad of the Mujahideen

\section{Problem statement}

According to Weberian theory, the monopoly of violence is held by the state, but what if the state is unable to protect itself from an internal threat? Since 2014, the Iraqi state has been defined as a state that is unable to fight and control the threat that from ISIS. It opened the door for the creation and spread of militias in order to fight the ISIS hazard. Now, these armed groups are acting as state representatives, and to a great extent, they challenge Prime Minister Haider Abdi's cabinet administratively and military. 


\section{Research questions}

The research questions will be designed theoretically:

1. What is the impact of religious militias, such as Hashed Shabi in Iraq, on the future form of the state?

2. Will the Shia armed groups be a destabilizing factor for Iraq and its neighbors?

\section{Purpose of the study}

In this study, we will focus on the implications of the Shia armed groups for the political situation in the Middle East, especially in Iraq. There is a relationship between non-state armed groups, the violent conflict and political stability. To prove this triangular relationship, we will look at the political situation in Iraq after ISIS. The rise of Shia groups during the last three years made the political situation in Iraq more complicated and unpredictable. The last three years have proven that these Shia armed groups have an overwhelming impact on socio-political stability not only for Iraq but also for its neighbors such as Syria. Therefore, the main focus here will be on the future of the political system in Iraq in light of these armed groups' activities and operations around the country.

\section{Research methods}

The methodology of this research project is theoretical. This research will adopt a theory of violence devolution and a theory of state/government militias. This will enable the researcher to explore what role or how much impact PMF will have in the process of state rebuilding in Iraq in the post-ISIS era.

\section{The reason for the existence of the militias}

The non-state armed groups and its reintegration into a national army is an interdisciplinary study that focuses on this process from different perspectives and different times. Historically the rise of non-state armed groups originated from the stat's struggle for monopolizing and consolidating of power, and beside it to secure as much territory as they could (Tilly). The creation of the modern state after the ending of the second world war results in a situation that many Europeans countries become institutionalized and established democracy (Dahm). From that point, the army became depoliticized and came under the legislative branches which it reconstructed and re-designated the army under the name national army 
with the responsibility for the country's border protection. The history of nonstate armed groups in the Middle East has had another role and function other than it has had in past in the pre-modern European. Ending of the colonization in the Middle East during the late 5oth shot a new phase for the creation of the nation-state. Most of the Arab state formed and developed into the so-called post-colonial. The distinguishing feature of the Arab post-colonial states is a consolidation of power and the struggle for the centralization. for example, post-colonial Iraqi state faced a tough rebel from its Kurds and by the time when the state became more and more Sunni sect-centric the Shia also marginalized.

According to Richard Jackson, insecurity in a weak state is one of the reasons for the creation of militias. The majority of Middle East states were defined as weak states, and the common characteristic among them is the insecurity challenge. Buzan claims that there are three elements central to the existence of a strong state:

1. The idea of the state;

2. Institutional capacity;

3. A physical base.

For Buzan, the idea of the state is essential to having a peaceful society, and he claims that society will reach a consensus regarding the state and identify with it. In the case of Iraq, it is difficult to find a broad and appropriate social consensus regarding the Iraqi state. For example, after the collapse of Saddam's regime, the majority of the Sunni boycotted the political process under the observation of the US. This led to resistance against both the Iraqi state and the US presence and finally led to the creation of Sunni insurgents.

A measurement and identification of the insecurity in weak states is that they are to a high degree more vulnerable to internal threats than to external threats. The Sunni insurgents and their disagreement with the Iraqi state exemplify the most difficult internal threat against the Iraqi state. Another perspective regarding the creation of the militias is from Max Weber. The Weberian theory is based on the assumption that the state is the only entity that has a monopoly of violence: "Weberian concept of the state, which views the state as a monolithic entity and as the only beholder of the monopoly of violence" (Balcells).

When the Iraqi state's establishments were unable to protect its internal and external security, then the existence of the militia became a natural consequence: "...Weberian accounts of militias as constitutive of state failure" (Carey).

For example, consider Lebanon when it became classified as a failed state. Consequently, militias such as the Hezbollah act as a state and present themselves as an alternative to the state. In so doing, they addressed many issues such as providing jobs by investing their money in small industries and offering free healthcare for poor people. The real cause of the existence of militias in Middle Eastern societies is the states' weakness and lack of legitimacy. 


\section{Post-Saddam Era and the Shia revival}

After the collapse of the Iraqi regime in 2003, the Americans decided to recreate a new regime on the basis of so-called "ethnic power sharing": Establishing a governmental system that can accommodate Iraq's different ethnic and religious groups (Brancati).

This meant that the Kurds, the Sunnis, and the Shias should participate in ruling the country. The Iraqi governing council (IGC), which was established three months after the occupation of Bagdad, was based on this principle. The IGC consisted of 25 members, and its ethnic and religious breakdown included 13 Shias, five Sunnis, five Kurds (also Sunnis), one Turkman and an Assyrian (Evans). On June 1, 2004, the IGC dissolved after the creation of the new Iraq interim government (IIG) as a caretaker government to govern Iraq until the drafting of the new constitution. The Iraqi transitional government replaced the IIG from May 3, 2005, until May 20, 2006, and it arranged an election to choose the national assembly on January 30 , 2005. This assembly drafted a permanent constitution, which was then submitted for approval by the Iraqi people in a general referendum. The new constitution was approved, and the Iraqi legislative authority was vested in two bodies: the Council of Representatives and the Council of Union. The post-Saddam period may be described as a rising of the Shia sect in Iraq and, at the same time, the exclusion of the Sunnis. The turning point for the Shia revival began with Said Ali Al-Sistani's (the most influential and famous Shia cleric) call for the Shias' active participation in the first parliamentary election in 2005. The majority of the Shia political parties combined themselves into a block to participate in that election with the aim of winning as many seats as possible - which they succeeded in doing (Cockburn) Even the majority of the Iraqi transnational government were Shias, and its prime minister was Ibrahim Jafari (a Shia politician), though this did not mean a return to stability for Iraq. This was because the majority of the Sunnis felt excluded and blamed for Saddam's brutal policy in Iraq, and this pushed the Sunnis to cooperate with terrorist groups such as Al-Qaida to fight against both the Americans in Iraq and the Iraqi government. Iraqi society under Jafary's cabinet faced a terrible period, and there was high level of sectarian conflict. The instability in Iraq continued until an unknown Shia politician (Nouri Al-Maliki) came into power. In an article published in Washington Post in 2014, Ali Khedery, an American Special Assistant to the US Ambassador and a Senior Adviser in Iraq (2003-2009), explained the process of choosing of Al-Maliki for the role of replacement for Jafari. According to Khedery, Al-Maliki was unknown to the former American Ambassador (Zalmay Khalilzad) and to most Iraqi people, but Khalilzad, after recommendations from Khedery and Jeffrey Beals, a former American diplomat, succeeded in garnering support among Iraqi leaders for giving Al-Maliki the position of prime minister (Khedery). On May 20, 2006, Al-Maliki became prime minister for Iraq and stayed 
in power until 2014. In the next part of this article, I will highlight the sectarian policy that was used by Al-Maliki during his eight years as prime minister against the majority of Sunnis in cities such as Anbar, Salahadin, Tikrit, and Mosul.

\title{
Al-Maliki's sectarian policy as a root cause of ISIS
}

Nouri Al-Maliki could, with support from the US, Kurds, Sistani, and Iran, return stability to the majority of Iraq. It was part of his political program to disarm Sunni and Shia militias in Baghdad, which he succeeded in doing.

\begin{abstract}
Al-Maliki said Iraqi society must be cleansed of terrorism, the government must be rid of 'administrative corruption' and factional militias must be disarmed. "We must also address the issue of government centrality and the centrality of the armed forces and that weapons must only be in the hands of the government and the people must be disarmed," he said.

He said that "no militia in Iraq can share authority with the government's armed forces" (Tures).
\end{abstract}

During his first term (2006-2010), Prime Minister Al-Maliki centralized power into his own hands and succeeded in transforming Iraq to single-party rule, and the majority of Shias supported his policy against the Sunnis. Ultimately, this resulted in the ethnic cleansing of Sunnis, especially in Baghdad, for example: Baghdad went from some $45 \%$ Sunni in 2003 to only $25 \%$ Sunni by the end of 2007 . Al-Maliki's sectarianism led to the transformation of Baghdad into a largely Shiite city (Cole).

The Shia monopoly corrupted the police, military, and court institutions. These institutions allowed only for candidates adhering to Shia principles and, especially during the Al-Maliki period, these candidates had to also be loyal to his party. Consequently, Sunnis were excluded from these establishments. In Sunni-dominated cities such as Al-Anbar, Al-Salahadin, and Mosul, people considered the police and court institutions to be a tool in the hands of Shias to eliminate Sunnis. This was the main cause of the dramatic seizure of power of these cities by ISIS, and the Sunnis observed their chance to get rid of the Shia tyranny. At this point, Iraq entered a new phase in which large parts of Sunni cities were under ISIS control, and the police and army were powerless to fight back.

One of the most important tasks of the nation-state from its beginnings was to protect its internal and external security. The same idea exists in the new modern nation-state: "The differentiation between internal and external security, and between police and military, has been a core principle of the modern nation-state" (Lutterbeck). 
Internal security is the responsibility of the police, but external security is a task for the military. This does not, however, mean that the state should only protect its external security using its own military. Many countries today do not protect their external security with a national military, and, instead, they tend to outsource it. The idea of outsourcing national security has attracted democratic states such as the USA and the UK. The US government has contracted with many private American military companies and security consulting firms, such as Blackwater, to provide security for their representatives in foreign countries (Hamilton).

Considering Iraq's internal and external security, it was difficult to see who was responsible for protecting the country's internal security due to the misuse of the security institutions. Under the former Prime Minister Nouri Al-Maliki, both the police and army were controlled by his Shia party, and all top positions in the defense system were directly affiliated with Al-Maliki.

\section{John Kerry's plan for Iraq}

After the unexpected collapse of the Iraqi military system in 2014, Sistani issued a fatwa for the Shia population to defend their city against ISIS. This fatwa transformed Shia identity toward a feeling of greater commitment to their sect than to their nation and generated a renewed desire among them for revenge. Simultaneously, the Iranian regime welcomed Sistani's fatwa, supplying the Iraqi government with intelligence and providing Hashed Shabi with training and new weapons. After the creation of Hashed Shabi, the Iraqi army's role changed from defending the country from any threat against its sovereignty to supporting and assisting the Shia militia. In contrast to Sistani's fatwa, and to get Sunnis involved in the war against ISIS, the US foreign minister John Kerry came up with a new idea, using a "National Guard" as part of the US plan for fighting against ISIS in Iraq:

\footnotetext{
...On Wednesday, Mr. Kerry held a whirlwind series of meetings in Baghdad with Haider al-Abadi, the new Iraqi prime minister, and other top Iraqi officials. Afterward, Mr. Kerry told reporters that Iraqi leaders had made sufficient political progress toward forming an inclusive government to warrant further cooperation with Iraq against ISIS, including efforts to help train Iraqi security forces. "We stand by Iraq as it continues to build a government that meets the needs of each of Iraq's diverse communities, Mr. Kerry said.
}

Mr. Kerry hailed the Iraqis' decision to create new National Guard units that would be recruited locally and given the main responsibility for security in their home areas. "The United States is prepared to provide technical advice and assistance in order to help the Iraqis move this very important initiative forward”, Mr. Kerry said (Gordon). 
The same idea/plan was used by Americans in 2006-2009 when they organized Sunni tribes in the Sunni-dominated cities under the so-called Al-Sahawat movement (Awakening Councils) to fight against Al-Qaida. In contrast to the Al-Sahawat, the National Guard should be an inclusive entity with representation from among all Iraqi ethnicities. The National Guard in Iraq represents the US strategy to combat ISIS and then reconstruct Iraq's security sector.

The main goals of the National Guard were the following:

1. The National Guard should replace the Iraqi army institution, and it should protect Iraq from sectarian divisions.

2. Kurdish fighters (Peshmerga) should also integrate at this time within the National Guard because the they were well-trained in comparison with Sunni and Shia fighters.

3. The integration of the Sunnis into the National Guard was one of the most important goals because, first, the Sunnis did not feel that they were allowed sufficient participation in the national army and the institution was used by Nouri Al-Maliki over 2006-2014 to consolidate his power. Second, this would eliminate the excuse used by ISIS that they were fighting for Sunnis' rights and their future in Iraq.

US officials said al-Abadi had promised to create a national guard of local fighters to secure Iraq's 18 provinces - each run by a governor. That would ensure that the Iraqi army and its mostly Shia force would not be in charge of security in Sunni regions. That would bring salaried jobs, government pensions and other benefits to areas of Iraq neglected during Al-Maliki's eight years in power and which proved a fertile breeding ground for Isis (Tran).

The Iraqi Parliament passed a new law establishing the National Guard, though this has not yet been approved because of the impossibility of gaining broad agreement between different fractions. There are many critics of the National Guard because, on the one hand, it gives legal permission to create a militia for each one of Iraq's 18 provinces and, on the other, it would militarize the whole of Iraqi society.

\section{The criteria for militias (PMF as a militia)}

In this section, the so-called Hashed-Alshabi and the proposal for a National Guard are evaluated according to militia criteria. "...it can describe anything between a dozen individuals armed with hunting rifles, to a force of millions equipped as well as a professional army" (Hawn). 
The above definition is one of the broadest explanations of the militia and, to some extent, it is difficult to use it to identify Hashed Al-shabi. Therefore, I think it is necessary to have another and more limited definition of militia. For an academic approach, Saeid Golkar's identification is used (Golkar):

1. Maintaining local defense.

2. Upholding law and order.

3. Violating human rights and fostering insecurity.

4. Controlling security in weak states.

5. Recruiting members from local communities.

The Shia militias can be identified by all these criteria. After the sudden collapse of Iraqi security in 2014, many cities of Iraq were in need of protection. Therefore, young men with access to guns organized themselves and took control of their communities. The militias in Iraq not only protected their cities but also began to attack other cities in revenge. For example, Shia groups such as the League of the Righteous, after they conquered the city of Tikrit, began to loot and kill the survivors. In addition, it is crucial to categorize these Iraqi militias in order to reveal to which militia type they belong. According to Ariel Ahram's book (Balcells) there are five types of militias, and they have a deep impact on the peaceful coexistence of society:

Table 1.

\begin{tabular}{|c|}
\hline Militia-Types \\
\hline Quasi-Official Militias \\
\hline State-Sponsored Militias \\
\hline Paramilitaries \\
\hline Warlords \\
\hline Pro-Government Militias (Carey, 4-6) \\
\hline
\end{tabular}

The Shia militias in Iraq can be seen as pro-government. This is because groups, such as Bader, League of the Righteous, Hezbollah in Iraq, and Sadr, were financed by the central government in Bagdad, show their loyalty to the central government, and coordinate their actions with the government. The coordination with the Iraqi government came about following a push from the US, as the leader of coalition forces against ISIS in Iraq. The coalition forces were concerned about the Shia militias' activities in the Sunni areas and their behavior toward the Sunni population. In addition to this, the US showed their concern with Iranian involvement and Iran's influence on these militias.

Finally, this argument underlines that the groups (Bader, League of the Righteous, Hezbollah in Iraq, Sadr) could be identified as pro-government with reference to the classification below by Sabine Carey, Neil Mitchell and Will Lowe: 
1. is identified as pro-government or sponsored by the government (national or subnational);

2. is identified as not being part of the regular security forces;

3. is armed;

4. has some level of organization (Carey, 249-258).

13. The Iraqi state as a hybrid state

According to many political scientists, such as Joakim Ekman, Jean-François Gagné, and Leonardo Morlino, the hybrid state is a phenomenon where the state is trapped between two structures: one is a non-democratic framework and the second is democratic (Ekman, 7-31). The state's institutions have difficulty adopting democratic behaviors because of their authoritarian background. The legitimacy of the state is not wholly lacking; rather, its legitimacy is acquired and exploited in dubious ways and often remains contested (Hague, 83-99). This is one of the most important drivers of the creation of militias in many Middle Eastern countries, including Iraq, Syria, Libya, Lebanon, and Yemen. According to Joakim Ekman, states that fit the hybrid regime profile can be identified based on the following characteristics (Ekman, 7-31):

1. Elections that are not too flawed and that have the potential to make a difference;

2. Significant levels of corruption, particularly in the judicial and electoral areas;

3. A lack of vital components of democratic quality, such as checks and balances and government accountability;

4. A problematic press freedom situation, typically including incumbents' desire to control the media, particularly television;

5. A poor civil liberties situation, including limits on the freedom of expression and the freedom to form organizations and trade unions; and

6. A problematic rule of law situation, including a lack of judicial independence. In addition, Amin Massoud, a Tunisian researcher, emphasizes four components that result in a hybrid state (Massoud):

1. The militias replace the military system.

2. Central government consists of sectarian cantons.

3. The legislative system is more than customary laws and less than constitutional provisions.

4. The political class (in power and the opposition alike) is made up of more than the advocates of communities and less than modern state builders and owners of institutional reform projects.

Iraq has transformed into a hybrid state because the central government in Bagdad was dominated by the Shia party. This means that the majority of Sunnis and Kurds did not see the central government as a cohesive national government, and many parts of this government's institutions such as the police, courts and the military therefore lacked legitimacy. When citizens lose their trust in the integrity of state institutions, they try to find alternatives. The Kurds have their own almost 
independent state, and they do not have strong ties to Baghdad. The Sunnis had already organized their tribal committee, which worked as a microgovernment in their areas before ISIS appeared in Mosul and Al-Anbar. The process of dividing Iraq is as likely to occur today as it has in past. The catalyst behind this process is the Shia militias that fight against ISIS. These militias have a legitimate right to use force against those they identify as Sunni, or at least the Sunni majority. In the following section, the focus will be on the criteria for creating a militia and evaluating the Shia's militia as a threat to peaceful coexistence.

\section{The war for geographical expansion}

According to an article from the Al-Rawabet Center for Research and Strategic Studies located in Amman, Jordan, there are approximately 67 armed Shia groups, and they operate in different regions of Iraq and in Syria. Each has its own name, leader, territory and religious marja (authority).

Table 2. Factions of The People's Mobilization Forces in Iraq and Syria (Rawabet Research and Strategic Studies Center 2016)

\begin{tabular}{|c|c|c|c|c|}
\hline $\mathrm{T}$ & The name & Leader & Working yard & $\begin{array}{c}\text { Religious Marja } \\
\text { (authority) }\end{array}$ \\
\hline 1 & $\begin{array}{c}\text { Saraya Al-salam / } \\
\text { Sadrist }\end{array}$ & $\begin{array}{c}\text { Kazem Hussein } \\
\text { Al-Issawi }\end{array}$ & $\begin{array}{c}\text { Iraq / Samarra } \\
\text { sector - Qayyarah }\end{array}$ & $\begin{array}{l}\text { Iraq: Mohammed } \\
\text { Sadiq al-Sadr, } \\
\text { Iran: Ayatollah } \\
\text { Khamenei }\end{array}$ \\
\hline 2 & $\begin{array}{l}\text { Badr-Corps- } \\
\text { military wing the } \\
\text { Badr Organization }\end{array}$ & Hadi al-Ameri & $\begin{array}{l}\text { Iraq - Salahuddin } \\
\text { sector, Diyala, } \\
\text { Syria }\end{array}$ & $\begin{array}{l}\text { Iran: Ayatollah } \\
\text { Khamenei }\end{array}$ \\
\hline 3 & $\begin{array}{c}\text { Kata'ib } \\
\text { Iraqi Hezbollah }\end{array}$ & Jaafar al-Ghanemi & $\begin{array}{c}\text { Iraq - Sector } \\
\text { of Anbar, Salah } \\
\text { al-Din / Nukhayib }\end{array}$ & $\begin{array}{l}\text { Iran: Ayatollah } \\
\text { Khamenei }\end{array}$ \\
\hline 4 & Asa'ib Ahl-Haq & Qais al-Khazali & $\begin{array}{c}\text { Iraq - Sector } \\
\text { of Salah al-Din / } \\
\text { Nukhayib, Syria }\end{array}$ & $\begin{array}{l}\text { Iran: Ayatollah } \\
\text { Khamenei }\end{array}$ \\
\hline 5 & $\begin{array}{l}\text { Kata'ib Sayyid } \\
\text { al-Shuhada }\end{array}$ & $\begin{array}{l}\text { Hashim Banyan ul- } \\
\text { Awliya: Abu Alaa }\end{array}$ & $\begin{array}{l}\text { Iraq - Sector } \\
\text { Baghdad belt, } \\
\text { Salah al-Din }\end{array}$ & $\begin{array}{l}\text { Iran: Ayatollah } \\
\text { Khamenei }\end{array}$ \\
\hline 6 & $\begin{array}{c}\text { Kata'ib Hezbollah } \\
\text { Al-Nujaba }\end{array}$ & $\begin{array}{c}\text { Akram Abbas, } \\
\text { al-Kaabi }\end{array}$ & $\begin{array}{c}\text { Iraq - Sector } \\
\text { of Baghdad belt, } \\
\text { Syria }\end{array}$ & $\begin{array}{l}\text { Iran: Ayatollah } \\
\text { Khamenei }\end{array}$ \\
\hline
\end{tabular}

For the rest of the figure, please see the supplemental pages. 
As we can see from the table 2, these Iraqi Shia militias have been used in the regional conflict and are now fighting to gain as much territory as possible. For example, groups such as the League of Righteous People (Asa'ib Ahl al-Haq), also known as the Khazali network, have their field of operation in the city of Duz (also spelled as Tuz Khurma and Tuz Khormato or just Khurmatu) is the central city of Tooz District in Saladin Province, Iraq, located 55 miles south of Kirkuk and the majority of its population are Kurds (Sunnis) and the minority are Turkmen (Shia). This group has been involved in heavy fighting against the Peshmerga (Kurdish fighters) and many from both sides have been killed. The presence of the Khazali group in Duz was not to fight ISIS, since the city was protected by Peshmerga and ISIS was not present. Instead, the overall aim of the Khazali group was (and still is) to dominate more areas. Their different fields of operation provide significant evidence of their struggles for more land and more control. Another aspect of these groups is that the majority of them have the current Iranian supreme leader and Muslim cleric Ayatollah Khamenei as their religious authority, meaning that they are unconditionally loyal to him. In other words, they are part of the Iranian policy in the Middle East, and they are now part of the proxy war in the region ${ }^{1}$. They have been supported by external regimes such as Iran, which means they are directly under the influence of Iranian policies, and they will be working in favor of Iran's betterment. Finally, Shia fighters have been part of the war in Syria, and some of them have been killed. The intervention of the Shiite militias in the Syrian conflict is considered to be the most dangerous transformation. During this transformation process, these groups have evolved from being local militias to being a regional militia and finally to being mercenaries, which means they can be used in any conflict in the Islamic world, such as in Syria, Yemen and, most likely, in Bahrain.

\section{Conclusion}

The sectarian policy of the Shia politicians has been supported by the majority of the Shia and by religious clerics such as Al-Sistani. This policy is believed to be the root of the creation of ISIS in the Sunni cities and is why the Sunni supported ISIS against the central government in Bagdad. The future of Iraq is still unclear, and the political process is moving toward a division of the country into three parts, which will be one of the best options. The Shia political parties are not willing to share power with the Sunnis and Kurds, and the Shia still insist on their unconditional right to rule as they want. The Iraqi population is facing two choices; one choice is to have approximately $40 \%$ of Iraq's territory controlled by ISIS, and

1 Middle East Eye Staff. Militias 'greater threat' to Iraq's unity than Islamic State: Petraeus. News, The Middle East Eye. 2015. http://www.middleeasteye.net/news/militias-greater-threat-iraqs -unity-islamic-state-petraeus-1595509838 
the second choice is to accept the existence of Shia militias. The concept and feeling of a unified national government have almost vanished. The Shia militias are now acting as the legitimate institution, and their capability to run the government is limited due to their lack of legitimacy. However, after defeat of ISIS by the people's mobilization force in Mosul and the change in the control of this city, these Shia armed groups will not accept any power that tries to push them out of the Iraqi political system. According to al-monitor, a series of secret meetings have been held between the people's mobilization force's representative and a diplomatic delegation from the West attempting to better understand these armed groups and their plan for the future of Iraq (Aziz). These groups have already started reorganizing themselves into a political party with the aim of participating in the next election, which will be in 2018 .

Conflicts of interest: The authors have no conflicts of interest to declare.

\section{Works Cited}

Aziz, J. What are Iraq's Popular Mobilization Units doing in Beirut? Lebanon pulse. “The Almonitor”, 2016. Web. http://www.al-monitor.com/pulse/originals/2016/08/ lebanon-host-secret-meeting-iraq-pmus-western-diplomats.html.

Balcells, L. Book review of proxy warriors: The Rise and Fall of State-Sponsored Militias - By Ariel Ahram. "Democracy and Security", no. 8 (2012), pp. 406-414. Brancati, D. Can Federalism Stabilize Iraq? “The Washington Quarterly”, no. 27 (2004), pp. 7-21.

Carey, S.C., Mitchell, N.J., \& Lowe, W. States, the security sector, and the monopoly of violence. "Journal of Peace Research", no, 50 (2013), pp. 249-258.

Cockburn, P. Cricket but no Chess in Sistani's Vision for Democratic Iraq. “The Independent News of the World", 2005. Web. http://www.independent.co.uk/ news/world/cricket-but-no-chess-in-sistanis-vision-for-democratic-iraq-1529714. html.

Cole, J. Top 10 Mistakes of Former Iraq PM Nouri al-Maliki (that ruined his country). "Juan Cole's Blog", 2014. Web. http://www.juancole.com/2014/08/mistakesMaliki-country.html.

Dahm, Jochen. Gombert, Tobias. Krell, Christian. Foundations of social democracy. "Akademie für Soziale Demokratie" (2017), pp. 79-85.

Ekman, J. Political participation and regime stability: A Framework for Analyzing Hybrid Regimes. "International Political Science Review", no. 30 (2009), pp. 7-31. Evans, G. Only self-rule will bring stability to Iraq. The Crisis Group. Op-ed, Middle East \& North Africa, 2003. Web. https://www.crisisgroup.org/middle-east-north-africa/ gulf-and-arabian-peninsula/iraq/only-self-rule-will-bring-stability-iraq. 
Golkar, S. Captive Society: The Basij Militia and Social Control in Iran. New York, NY: Columbia University Press, 2015.

Gordon, M., \& Schmitt, E. Saudi Arabia will grant US request for anti-ISIS training program. "The New York Times", 2014. Web. https://www.nytimes.com/2014/09/11/ world/middleeast/saudi-arabia-isis.html?_r=1.

Hague, R., \& Harrop, M. Comparative Government and Politics. Basingstoke, UK: Palgrave Macmillan, 2010, pp. 83-99.

Hamilton, S. Outsourcing US defense: National security implications - UPDATED: Industry insights. “The National Defense”, 2011. Web. http://www. nationaldefensemagazine.org/archive/2011/January/Pages/OutsourcingUS DefenseNationalSecurityImplications.aspx.

Hawn, J. Intro to global security: Defining mercenaries and militias, 2013. Web. http:// introglobalsecurity.blogspot.com/2013/02/defining-mercenaries-and-militias. html.

Khedery, A. Why we stuck with Maliki - and lost Iraq. "The Washington Post. Opinions", 2014. Web. https://www.washingtonpost.com/opinions/why-we-stuckwith-maliki--and-lost-iraq/2014/07/03/0dd6a8a4-f7ec-11e3-a606-946fd632f9f1_ story.html?utm_term=.c59ala63d94f.

Lutterbeck, D. Between Police and Military: The New Security Agenda and the Rise of Gendarmeries. "Cooperation and Conflict", no. 39 (2004), pp. 46-47.

Massoud, A. About hybrid countries in the Arab world. "The Arab Weekly Newspaper", 2015. Web. http://www.alarab.co.uk/article/Opinion/53177/\%D8\%B9\%D9\%86.

Tilly, Charles. Irregular Armed Forces and Their Role in Politics and State Formation. Cambridge University Press, 2003, pp. 37-80.

Tran, M., \& Roberts, D. Obama to lay out plan to 'destroy' Isis threat as Kerry arrives in Baghdad. "The Guardian", 2014. Web. https://www.theguardian.com/ world/2014/sep/10/john-kerry-baghdad-obama-isis-strategy.

Tures, J. How we enabled ISIS by disarming Iraqi militias. Huffington Post. "The Blog", 2014. Web. http://www.huffingtonpost.com/john-a-tures/how-we-enabled-isis-bydi_b_5947796.html.

Kardo Rached is a lecturer at University of Human Development - Kurdistan Region of Iraq. He has published various articles and his research field covers the political systems of the Middle East and the role of the non-state actors in Middle East society.

Ahmed Omar Bali is lecturer at University of Human Development - Kurdistan Region of Iraq. Dr. Bali has got his PhD from Sheffield University and his research area includes public diplomacy and soft power's role in the Middle East politics. 